\title{
PENGARUH MODEL PEMBELAJARAN KOOPERATIF DENGAN PENDEKATAN PROBLEM POSING DITINJAU DARI PENGETAHUAN AWAL TERHADAP KEMAMPUAN PEMECAHAN MASALAH FISIKA SISWA SMK
}

\author{
Siti Nurdatul Jannah*, Aris Doyan, Ahmad Harjono \\ Program Studi Magister Pendidikan IPA \\ Program Pascasarjana Universitas Mataram \\ Email: nurdatul_jannah@yahoo.com
}

\begin{abstract}
This study aims to determine the effect of cooperative learning through problem posing approach to the students' problem solving skills in terms of prior knowledge. The method used is a quasi-experimental method with $2 \times 2$ factorial study design. The study population was 163 students of class XI SMKN 9 Mataram scattered in 5 classes. These samples included 55 students, divided into two classes by cluster of random sampling technique. The research instrument is a test mastery of concepts and problem solving skills test given at the beginning and end of the study. The data was analyzed by Manova two ways. (1) students learn to use cooperative learning model with problem posing approach was significantly different in the aspect of problem solving ability than students who study with learning cooperative model only, (2) students who have high prior knowledge different significantly in aspects of problem solving ability compared students who have low prior knowledge, (3) there was not an interaction effect between learning model with prior knowledge of the problem solving ability students
\end{abstract}

Keywords: Cooperative Learning Model, Problem Posing, Prior Knowledge, Problem Solving Skills

\section{Pendahuluan}

Salah satu tujuan diselenggarakannya pembelajaran fisika di tingkat SMK adalah melatih siswa untuk menggunakan konsep dan prinsip fisika guna menjelaskan berbagai peristiwa alam dan menyelesaian masalah baik secara kualitatif maupun kuantitatif. Berdasarkan pada tujuan ini, mata pelajaran fisika disampaikan kepada siswa tidak hanya sekedar memberikan pemahaman konsep kepada siswa namun agar siswa juga mampu menggunakan konsep-konsep tersebut untuk menyelesaikan permasalahan yang ada di sekitarnya. Hassard \& Dias (2009) mendefinisikan kemampuan pemecahan masalah adalah kemampuan dalam bentuk langkah-langkah yang berurutan yang dibutuhkan untuk menemukan solusi dari sebuah pertanyaan.

Keterampilan dalam memecahkan masalah sangat berguna bagi siswa dalam memecahkan masalah dalam kehidupan sehari-hari. Oleh karena itu, yang dapat dilakukan oleh guru adalah memperbaiki kualitas proses pembelajaran fisika, agar proses pembelajaran fisika dapat terlaksana dengan mengacu pada tujuan pembelajaran fisika yang ditetapkan dalam KTSP yaitu pembelajaran fisika yang memotivasi siswa untuk berpartisipasi aktif dan memberikan ruang dan kesempatan kepada siswa untuk mengembangkan pengetahuan dan sikap-sikap ilmiahnya melalui pemberian pengalaman pembelajaran yang bermakna.

Pembelajaran fisika yang berlangsung selama ini di SMK Negeri 9 Mataram masih banyak mementingkan menghapal konsep dan prinsip-prinsip sains secara verbal, ranah pengembangan kemampuan siswa untuk memecahkan masalah melalui pembelajaran fisika tidak terlaksana. Cara pembelajaran yang berlangsung seperti ini menyebabkan siswa pada umumnya hanya mengenal peristilahan-peristilahan fisika secara hafalan tanpa makna. Selain itu banyaknya konsep-konsep dan prinsip-prinsip sains yang perlu dipelajari siswa, menyebabkan munculnya kejenuhan siswa dalam belajar fisika.

Hakekat pembelajaran sains sesungguhnya adalah bagaimana membantu siswa agar mampu berpikir independen melalui pendekatan kognitif dan konstruktivisme serta mampu memecahkan masalah sains melalui media-media dan proyek-proyek sains [1]. Oleh karena itu perlu diupayakan bagaimana meningkatkan dan mengembangkan kualitas pembelajaran fisika yang mengarah kepada pembelajaran pada keterampilan berpikir tingkat tradisional menjadi pengajaran yang bertujuan untuk mengembangkan keterampilan berpikir kreatif siswa sehingga siswa tidak hanya mampu menghafal konsep-konsep sains, melainkan mampu berpikir independen untuk menguasai konsep-konsep sains dan mampu memecahkan masalah-masalah sains.

Salah satu model pembelajaran yang menyediakan kesempatan bagi siswa untuk melakukan pengembangan penguasaan konsep dan pemecahan masalah sains adalah model pembelajaran kooperatif dengan pendekatan problem posing. Model pembelajaran ini menitik beratkan pada perumusahan masalah dari suatu keadaan yang terjadi baik dilakukan sebelum, ketika, atau setelah pemecahan masalah. Problem posing berorientasi 
pada aktivitas dan keterlibatan siswa secara aktif dalam memahami materi pembelajaran, mengembangkan kemampuan berpikir siswa dalam menyelesaikan masalah serta menimbulkan sikap positif terhadap fisika. Membiasakan siswa dalam merumuskan, menghadapi dan menyelesaikan soal merupakan salah satu cara untuk mencapai penguasaan suatu konsep menjadi lebih baik [2]. Penelitian yang telah dilakukan oleh Hakim (2010) yang menerapkan model pembelajaran kooperatif dengan pendekatan problem posing pada materi kesetimbangan benda tegar menyimpulkan bahwa model pembelajaran kooperatif dengan pendekatan problem posing berpengaruh terhadap pemahaman konsep dan keterampilan berpikir kritis siswa kelas XI SMA.

Dalam kaitannya dengan proses pembelajaran, pengetahuan awal (prior knowledge) merupakan hal penting yang perlu dipertimbangkan, akan tetapi sangat jarang guru yang menerapkan proses pengukuran pengetahuan awal siswa [3]. Kuantitas pengetahuan awal siswa akan memberi dampak pada kemampuan siswa dalam mengakuisisi pemahaman yang akan diterimanya [4]. Dochy dalam Hailakiri, et al., (2008) mendefinisikan pengetahuan awal merupakan entitas multidimensi dan hirarki yang bersifat dinamis dan terdiri dari berbagai jenis pengetahuan dan keterampilan siswa. Berdasarkan paparan tersebut, tujuan penelitian ini adalah untuk mengetahui pengaruh model pembelajaran kooperatif melalui pendekatan problem posing terhadap kemampuan pemecahan masalah siswa ditinjau dari pengetahuan awal.

\section{TinjaUAn PUSTAKa}

\section{A. Model Pembelajaran Kooperatif dengan Pendekatan Problem posing}

Problem posing merupakan salah satu pendekatan pembelajaran yang berbasis konstruktivisme. Penekanan dari teori ini adalah siswa sebagai pelajar tidak hanya menerima pengetahuan tapi secara aktif mengkonstruksinya secara individual. Problem posing didefinisikan sebagai proses menciptakan sebuah permasalahan baru berdasarkan kriteria atau pengalaman tertentu, atau proses membuat perumusan ulang dari sebuah permasalahan yang diberikan [5]. Sementara itu English (1997) menyatakan bahwa pendekatan problem posing dalam pembelajaran dapat meningkatkan kemampuan berpikir siswa, kemampuan memecahkan masalah, meningkatkan kemampuan siswa dalam pemecahan masalah yang bersifat matematis, serta memperluas pemahaman matematis siswa [6].

Stoyanova (1998) mengklasifikasikan perumusan masalah dalam problem posing ke dalam tiga kategori yaitu: (1) merumuskan masalah dalam situasi bebas, (2) merumuskan masalah dengan jawaban yang sudah diberikan sebelumnya, dan (3) merumuskan masalah berdasarkan informasiinformasi penting [7]. Sementara itu Silver (1996) mengklasifikasikan problem posing berdasarkan pada waktu pemberian masalah, yaitu: (1) dirumuskan sebelum pemecahan masalah diberikan secara keseluruhan baik yang diwujudkan dalam bentuk naskah, gambar, diagram, tampilan, dan sebagainya, (2) dirumuskan selama proses pemecahan masalah ketika siswa berkonsentrasi terhadap masalahmasalah yang dihadapi, dan (3) dirumuskan setelah memecahkan masalah ketika siswa sudah mendapatkan pengalaman dari pemecahan masalah sebelumnya, yang selanjutnya diterapkan untuk situasi baru [6].

Model pembelajaran kooperatif dengan pendekatan problem posing merupakan model pembelajaran kooperatif yang ditujukan pada pembentukan dan perumusan masalah oleh siswa yang dilakukan secara berkelompok. Berdasarkan uraian di atas, langkah-langkah model pembelajaran kooperatif dengan pendekatan problem posing adalah sebagai berikut: 1) Menyampaikan tujuan dan mempersiapkan siswa, 2) Menginformasikan materi pembelajaran, 3) Mengorganisasi siswa ke dalam kelompok-kelompok belajar, 4) Membimbing kelompok untuk bekerja dan belajar, 5) Mempresentasikan hasil diskusi dan membuat rangkuman, 6) Evaluasi dan 7) Memberikan penghargaan.

\section{B. Pengetahuan Awal}

Marzano (2004) mendefinisikan pengetahuan awal sebagai "what can be thought of as "packets" of information". Sementara itu, Dochy (1999) mendefinisikan pengetahuan awal sebagai entitas multidimensi dan hirarki yang bersifat dinamis dan terdiri dari berbagai jenis pengetahuan dan keterampilan siswa [4]. Pengetahuan awal siswa merupakan sekumpulan informasi yang dapat menjembatani sejauh mana pemahaman lain dapat dipergunakan [3]. Pengetahuan awal yang baik akan membantu siswa dalam mengembangkan pemahaman selanjutnya dari materi yang dipelajari [8].

Pengetahuan awal yang dimiliki oleh siswa dapat diperoleh melalui kemampuan guru dalam memproses informasi yang tersimpan tersebut [9]. Sementara itu, Angelo \& Cross (1993) menyatakan bahwa pengetahuan awal siswa yang berhubungan dengan topik tertentu dapat diukur melalui daftar pertanyaan-pertanyaan ringan yang diisi oleh siswa.

Dari beberapa pengertian tersebut dapat disimpulkan bahwa pengetahuan awal siswa adalah sejumlah informasi yang dimiliki oleh siswa yang berkaitan dengan materi yang akan dipelajai siswa, yang dapat membantunya dalam memahami materi tersebut lebih lanjut. Untuk mengetahui kemampuan 
awal siswa terhadap materi yang akan diberikan maka diberikan soal pretest berupa soal pengetahuan awal dalam bentuk essai. Dari soal pengetahuan awal diharapkan siswa mempunyai gambaran konsep tentang materi yang akan diberikan, dalam hal ini materi getaran, gelombang dan bunyi. Dari hasil tes pengetahuan awal siswa kemudian dibagi menjadi dua kelompok yaitu kelompok siswa dengan pengetahuan awal tinggi dan kelompok siswa dengan pengetahuan awal rendah.

\section{Kemampuan Pemecahan Masalah}

Kemampuan pemecahan masalah didefinisikan sebagai sebuah proses menggunakan kemampuan untuk menjawab sebuah permasalahan melalui langkah-langkah: (1) mengidentifikasi hambatanhambatan guna mencapai tujuan, (2) mengidentifikasi cara-cara alternatif untuk mencapai tujuan, (3) mengevaluasi cara-cara alternatif tersebut, dan (4) memilih dan menggunakan alternatif tersebut [10]. Kemampuan pemecahan masalah adalah kemampuan dalam bentuk langkah-langkah yang berurutan yang dibutuhkan untuk menemukan solusi dari sebuah pertanyaan. Dalam pembelajaran sains, pemilihan langkah-langkah tersebut memiliki dua pertimbangan, yaitu: (1) langkah yang umum dipergunakan dalam penyelesaian masalah-masalah sains dan (2) mempertimbangkan bentuk permasalahan sains dalam menentukan langkahlangkah penyelesaian [1]. Sejalan dengan itu Gagne mendefiniskan kemampuan pemecahan masalah sebagai kemampuan seseorang dalam menggabungkan berbagai aturan untuk menghasilkan langkah-langkah dalam bentuk aturan baru yang tingkatannya lebih tinggi [11].

Berdasarkan beberapa definisi tersebut, kemampuan pemecahan masalah merupakan kemampuan yang sangat penting yang perlu dikembangkan dalam pembelajaran sains dimana merupakan kombinasi dari pemahaman seseorang untuk diterapkan dalam sebuah prosedur guna mencari jalan keluar terhadap sebuah permasalahan.

Dalam kaitannya dengan tahap-tahap pemecahan masalah, Dewey menjelaskannya dalam enam tahap, yaitu: (1) merumuskan masalah, (2) menelaah masalah, (4) merumuskan hipotesis, mengumpulkan dan mengelompokkan data sebagai bahan pembuktian hipotesis, (6) pembuktian hipotesis, dan (6) menentukan pilihan penyelesaian [12]. Dalam merumuskan masalah kemampuan yang diperlukan adalah mengetahui permasalahan secara jelas, sedangkan dalam tahap menelaah masalah adalah menggunakan pengetahuan untuk memperinci dan menganalisis masalah dari berbagai sudut. Merumuskan hipotesis merupakan kemampuan berimajinasi dan menghayati ruang lingkup, sebab akibat, dan alternatif penyelesaian, sedangkan dalam pembuktian hipotesis diperlukan kemampuan mencari dan menyusun data, serta menyajikan data tersebut dalam bentuk diagram, gambar, atau tabel. Dalam membuktikan hipotesis diperlukan kemampuan menelaah data, membahas data, menghubungkan antara data satu dengan yang lain, serta menghitung data. Selain itu di dalam membuktikan hipotesis juga diperlukan kecakapan dalam mengambil kesimpulan dan keputusan. Pada tahap menentukan pilihan penyelesaian diperlukan kecakapan membuat alternatif penyelesaian yaitu menilai pilihan dengan memperhitungkan akibat yang terjadi pada setiap pilihan tersebut [12].

Berdasarkan tahap-tahap yang disebutkan diatas, dapat disimpulkan bahwa tahap-tahap pemecahan masalah dalam fisika meliputi: (1) mendeskripsikan konsep fisika berdasarkan masalah, (2) merencanakan solusi, (3) melaksanakan solusi, dan (4) mengecek dan mengevaluasi solusi. Mendeskripsikan konsep fisika meliputi menggunakan prinsip yang telah diidentifikasi maupun mendeskripsikan hubungan kualitatif dari variabel-variabel yang terdapat dalam masalah. Merencanakan solusi meliputi menyatakan permasalahan dengan persamaan-persamaan yang relevan untuk menyelesaikan masalah. Melaksanakan solusi yaitu mensubtitusikan semua variabel yang diketahui ke dalam persamaan yang sesuai dan melakukan perhitungan. Mengecek dan mengevaluasi solusi yaitu mengecek apakah permasalahan telah diselesaikan sepenuhnya dan apakah jawaban yang diberikan relevan dengan rencana yang ditetapkan sebelumnya.

\section{Metode Penelitian}

Penelitian ini merupakan penelitian eksperimen semu (quasi experiment) dengan desain faktorial $2 \times 2$ yang dilaksanakan dengan rancangan kelas acak. Rancangan penelitian terlihat pada Tabel 1 .

Tabel 1. Desain Penelitian Faktorial 2x2

\begin{tabular}{|c|c|c|c|}
\cline { 3 - 4 } \multicolumn{2}{c|}{} & \multicolumn{2}{c|}{ Kooperatif } \\
\cline { 3 - 4 } \multicolumn{2}{c|}{$\begin{array}{c}\text { Kooperatif } \\
\text { Pengetahuan } \\
\text { Awal } \\
\text { posing }\left(\mathrm{A}_{1}\right)\end{array}$} & $\begin{array}{c}\text { Kooperatif } \\
\left(\mathrm{A}_{2}\right)\end{array}$ \\
\cline { 2 - 4 } & $\begin{array}{c}\text { Tinggi } \\
\text { Rendah } \\
\left(\mathrm{B}_{2}\right)\end{array}$ & $\mathrm{A}_{1} \mathrm{~B}_{1}$ & $\mathrm{~A}_{2} \mathrm{~B}_{1}$ \\
\hline
\end{tabular}

\section{Keterangan:}

$\mathrm{A}_{1} \mathrm{~B}_{1}=$ Sel kemampuan pemecahan masalah kelompok siswa dengan pengetahuan awal tinggi yang mendapatkan perlakuan model pembelajaran kooperatif dengan pendekatan problem posing

$\mathrm{A}_{2} \mathrm{~B}_{1}=$ Sel kemampuan pemecahan masalah kelompok siswa dengan pengetahuan awal tinggi yang mendapatkan perlakuan model pembelajaran kooperatif 


\section{$\mathrm{A}_{1} \mathrm{~B}_{2}=$ Sel kemampuan pemecahan masalah kelompok siswa dengan pengetahuan awal rendah yang mendapatkan perlakuan model pembelajaran kooperatif dengan pendekatan problem posing \\ $\mathrm{A}_{2} \mathrm{~B}_{2}=$ Sel kemampuan pemecahan masalah kelompok siswa dengan pengetahuan awal rendah yang mendapatkan perlakuan model pembelajaran kooperatif}

Populasi dalam penelitian ini adalah siswa kelas XI SMK Negeri 9 Mataram yang terdiri atas 5 kelas dengan jumlah siswa 163 orang. Sampel penelitian dipilih secara acak dengan teknik cluster random sampling. Dalam penelitian pendidikan, cluster random sampling dipilih dengan tujuan untuk memudahkan memilih kelompok individu daripada memilih individu dari anggota populasi [13]. Dengan menggunakan cluster random sampling diperoleh satu kelas sebagai kelas eksperimen dan satu kelas sebagai kelas kontrol.

Instrumen penelitian kemampuan pemecahan masalah berupa tes essai yang berjumlah 5 soal. Tes ini digunakan untuk mengukur kemampuan siswa dalam memecahkan permasalahan-permasalahan fisika yang berkaitan dengan materi getaran, gelombang, dan bunyi. Instrumen tes mempertimbangkan tahap-tahap pemecahan masalah yaitu: (1) mendeskripsikan konsep fisika berdasarkan masalah, (2) merencanakan solusi, (3) melaksanakan solusi, dan (4) mengecek dan mengevaluasi solusi.

Analisis terhadap hasil tes pengetahuan awal siswa dipergunakan persamaan $Z_{\text {score, }}$ yaitu:

$$
Z_{\text {score }}=\frac{x-\mu}{s} \ldots \ldots \ldots \ldots \ldots \ldots \ldots \ldots(1)
$$

\section{Keterangan:}

$\mathrm{x}=$ nilai masing-masing sampel

$\mu=$ nilai rata-rata

$\mathrm{s}=$ simpangan baku

Berdasarkan hasil hasil $z_{\text {score }}$ selanjutnya dikelompokkan sebagai berikut: (1) nilai $\mathrm{z}_{\text {score }} \leq 0$ masuk pada kelompok pengetahuan awal rendah, dan (2) nilai $Z_{\text {score }}>0$ masuk pada kelompok pengetahuan awal tinggi [14].

Peningkatan kemampuan pemecahan masalah siswa dapat diketahui dengan menghitung besar skor gain yang dinormalisasi (N-gain). Hal ini dimaksudkan untuk menghindari kesalahan dalam menginterpretasikan perolehan gain masing-masing siswa. Untuk memperoleh skor $\mathrm{N}$ - gain digunakan rumus yang dikembangkan oleh Hake yaitu

$$
N-\text { gain }=\frac{S_{\text {post }}-S_{p r e}}{S_{\text {maks }}-S_{p r s}}
$$

Keterangan:

Spost $=$ skor tes akhir

Spre $=$ skor tes awal

Smaks $=$ skor maksimal

Dengan kategori perolehan N-gain: $\mathrm{g}>0,7=$ tinggi; $0,3=$ sedang dan $\mathrm{g} \leq 0,3=$ rendah [15].

Uji hipotesis statistik diawali dengan uji normalitas dengan Chi Square Test dan uji homogenitas dengan Uji F, selanjutnya dilakukan uji Anava dua jalur pada taraf signifikan 0,05. Analisis data dibantu dengan program aplikasi Microsoft Office Excel versi 2010 dan SPSS versi 18 for Windows.

\section{Hasil dan Pembahasan}

Kemampuan pemecahan masalah diukur berdasarkan tahap-tahap berikut yaitu: mendeskripsikan konsep fisika berdasarkan masalah, merencanakan solusi, melaksanakan solusi, dan mengecek dan mengevaluasi solusi. Hasil penelitian menunjukkan bahwa kelas dengan penerapan model pembelajaran kooperatif dengan pendekatan problem posing lebih baik dibandingkan kelas dengan model pembelajaran kooperatif saja. Skor rata-rata postes kemampuan pemecahan masalah siswa pada kelas eksperimen adalah 72,04 sedangkan pada kelas kontrol sebesar 45,57 (Tabel 2). Temuan ini secara deskriptif mengindikasikan bahwa penerapan model pembelajaran kooperatif dengan pendekatan problem posing lebih baik dibandingkan model pembelajaran kooperatif saja.

Tabel 2. Data Pretes dan Postes Kemampuan Pemecahan Masalah setiap Kelas Perlakuan

\begin{tabular}{lccccc}
\hline $\begin{array}{c}\text { Kelas } \\
\text { Perlakuan }\end{array}$ & N & $\begin{array}{c}\text { Rerata } \\
\text { Pretes }\end{array}$ & $\begin{array}{c}\text { S. } \\
\text { Dev }\end{array}$ & $\begin{array}{c}\text { Rerata } \\
\text { Postes }\end{array}$ & $\begin{array}{c}\text { S. } \\
\text { Dev }\end{array}$ \\
\hline Eksperimen & 28 & 59,29 & 12,28 & 72,04 & 11,55 \\
Kontrol & 27 & 38,08 & 6,09 & 45,57 & 11,63 \\
\hline
\end{tabular}

Kemampuan pemecahan masalah siswa yang memiliki pengetahuan awal tinggi lebih baik daripada siswa dengan pengetahuan awal rendah. Nilai ratarata kemampuan pemecahan masalah siswa dengan pengetahuan awal tinggi sebesar 63,90 sedangkan siswa dengan pengetahuan awal rendah sebesar 52,02 (Tabel 3).

Tabel 3. Data Pretes dan Postes Kemampuan Pemecahan Masalah Ditinjau dari Pengetahuan Awal 


\begin{tabular}{lccccc}
\hline $\begin{array}{c}\text { Pengetahuan } \\
\text { Awal }\end{array}$ & \multirow{2}{*}{ N } & $\begin{array}{c}\text { Rerata } \\
\text { Pretes }\end{array}$ & $\begin{array}{c}\text { S. } \\
\text { Dev }\end{array}$ & $\begin{array}{c}\text { Rerata } \\
\text { Postes }\end{array}$ & S.Dev \\
\hline Tinggi & 28 & 55,68 & 15,72 & 63,90 & 19,28 \\
Rendah & 27 & 41,83 & 8,60 & 52,02 & 15,54 \\
\hline
\end{tabular}

Ditinjau dari N-gain pemecahan masalah, kelas eksperimen $(0,32)$ memiliki nilai $\mathrm{N}$-gain lebih tinggi dibandingkan kelas kontrol $(0,10)$. N-gain pada kelas eksperimen berkategori sedang sementara pada kelas kontrol berkategori rendah (Gambar 1).

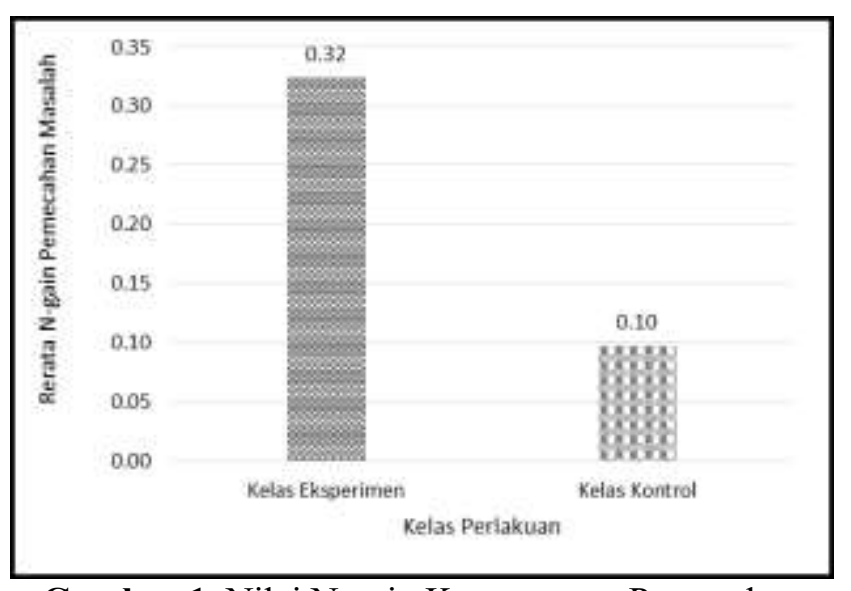

Gambar 1. Nilai N-gain Kemampuan Pemecahan Masalah

Siswa yang belajar menggunakan model pembelajaran kooperatif dengan pendekatan problem posing dilengkapi dengan lembar kerja siswa dan lembar problem posing. Kegiatan dalam proses pembelajaran menekankan pada kemampuan siswa dalam merumuskan soal dan penyelesaiannya yang dapat mengembangkan kemampuan berpikir siswa, sehingga kemampuan siswa dalam memecahkan masalah juga semakin baik. Hal ini terjadi karena saat siswa mengemukakan soal/masalah, secara tidak langsung telah memikirkan jawabannya. Dengan demikian, siswa menjadi terlatih berpikir aktif, kreatif dan produktif, sehingga pembelajaran lebih bermakna dan siswa lebih mudah dalam menyelesaikan masalah fisika.

Nilai pretes dan postes kemampuan pemecahan masalah mulai dari yang tertinggi sampai terendah secara berturut-turut diraih oleh interaksi model pembelajaran kooperatif melalui pendekatan problem posing dengan pengetahuan awal tinggi $\left(\mathrm{A}_{1} \mathrm{~B}_{1}\right)$, kemudian interaksi model pembelajaran kooperatif melalui pendekatan problem posing dengan pengetahuan awal rendah $\left(\mathrm{A}_{1} \mathrm{~B}_{2}\right)$, selanjutnya interaksi model pembelajaran kooperatif dengan pengetahuan tinggi $\left(\mathrm{A}_{2} \mathrm{~B}_{1}\right)$, dan terendah diraih oleh interaksi model pembelajaran kooperatif dengan pengetahuan rendah $\left(\mathrm{A}_{2} \mathrm{~B}_{2}\right)$. Data pretes dan postes kemampuan pemecahan masalah pada masing-masing interaksi antara model pembelajaran dengan pengetahuan awal disajikan pada Gambar 2.

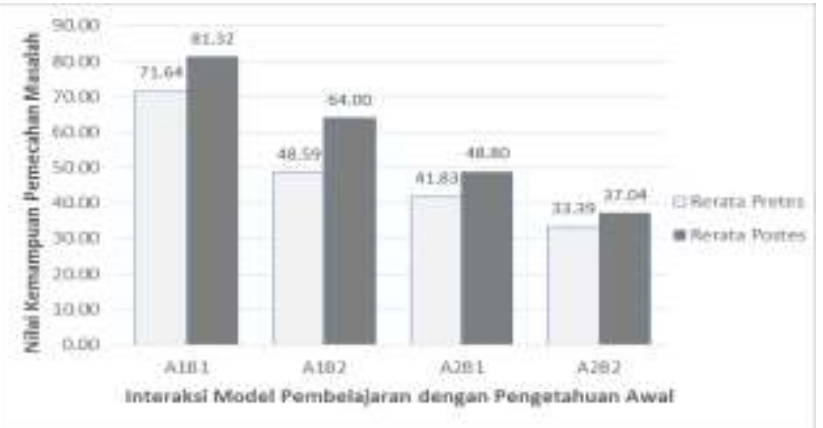

Gambar 2. Nilai Rerata Interaksi Model Pembelajaran dengan Pengetahuan Awal terhadap Kemampuan Pemecahan Masalah

Model pembelajaran kooperatif dengan pendekatan problem posing dapat membantu siswa dalam mengembangkan kesukaannya terhadap fisika, sebab ide-ide fisika siswa diarahkan untuk memahami soal yang sedang dikerjakan dan dapat meningkatkan pemahamannya dalam memecahkan suatu permasalahan. Selain itu siswa juga dilatih untuk mengkomunikasikan pertanyaan dengan bahasanya sendiri serta melatih keberanian dan kepercayaan diri siswa. Hal ini karena pembelajaran berbasis problem posing menuntut siswa agar dapat menyampaikan suatu masalah yang belum dia ketahui pemecahannya dari berbagai sumber belajar yang telah mereka pelajari dalam bentuk sebuah pertanyaan yang mereka susun secara mandiri dan disampaikan kepada sesama siswa maupun guru pada saat kegiatan pembelajaran untuk mendapatkan pemecahan masalahnya.

Kegiatan pembelajaran dengan menggunakan model pembelajaran kooperatif dengan pendekatan problem posing dapat melatih dan membiasakan siswa untuk berpikir kritis, meliputi kegiatan merumuskan masalah/pertanyaan, mencari solusi permasalahan, dan bekerja sama dengan anggota kelompok. Kegiatan kerja sama akan melatih siswa untuk mengemukakan pendapat dan mempertimbangkan pendapat teman, sehingga dapat menemukan solusi terbaik untuk mengatasi permasalahan sesuai dengan kesepakatan.

Data kemampuan pemecahan masalah siswa terdistribusi normal dan memiliki varian yang homogen (Tabel 4 dan Tabel 5).

Tabel 4. Hasil Uji Normalitas (Chi-square test) Data Kemampuan Pemecahan Masalah

\begin{tabular}{|c|c|c|c|c|}
\hline $\begin{array}{c}\text { Kelompok } \\
\text { Data }\end{array}$ & $\begin{array}{c}X^{2} \\
\text { hitung }\end{array}$ & Df & $\begin{array}{c}X_{\text {tabe }}^{2} \\
1\end{array}$ & Keputusan \\
\hline Pretes & $\begin{array}{c}17,65 \\
5\end{array}$ & 35 & $\begin{array}{c}49,8 \\
01\end{array}$ & Normal \\
\hline Postes & $\begin{array}{c}15,63 \\
6\end{array}$ & 36 & $\begin{array}{c}50,9 \\
98\end{array}$ & Normal \\
\hline
\end{tabular}

Tabel 5. Hasil Uji Homogenitas (Uji F) Data Kemampuan Pemecahan Masalah \begin{tabular}{llllll}
\hline $\mathrm{N}$ & Kelom & $\mathrm{F}_{\text {hitun }}$ & $\mathrm{F}_{\text {tabel }}$ & Kesimpul & Keputus \\
\hline
\end{tabular} 


\begin{tabular}{cccccc}
\hline o & pok & g & & an & an \\
& Data & & & & \\
\hline \multirow{2}{*}{1} & Pretes & 1,08 & 1,92 & $\mathrm{~F}_{\text {hitung }}<$ & Homoge \\
& & 6 & 1 & $\mathrm{~F}_{\text {tabel }}$ & $\mathrm{n}$ \\
2 & Postes & 1,01 & 1,92 & $\mathrm{~F}_{\text {hitung }}<$ & Homoge \\
& & 3 & 1 & $\mathrm{~F}_{\text {tabel }}$ & $\mathrm{n}$ \\
\hline
\end{tabular}

Model pembelajaran kooperatif dengan pendekatan problem posing dapat meningkatkan kinerja siswa dalam memecahkan masalah. Siswa mampu merumuskan masalah dan menentukan prosedur penyelesaian ketika diberikan masalah, karena selama ini siswa langsung menentukan hasil akhirnya tanpa merumuskan dan menentukan prosedur penyelesaiannya. Hal ini dikarenakan pendekatan problem posing dapat meningkatkan kreativitas siswa, aktivitas belajar siswa, pemahaman siswa, kemampuan penalaran, dan komunikasi siswa, serta meningkatkan kemampuan siswa dalam memecahkan masalah fisika.

Tabel 6. Hasil Uji Hipotesis Kemampuan Pemecahan Masalah

\begin{tabular}{ccccc}
\hline $\mathrm{N}$ & Sumber & $\mathrm{Df}$ & $\mathrm{F}_{\mathrm{h}}$ & $\begin{array}{c}\mathrm{P} \\
\text { (sig.) }\end{array}$ \\
\hline 1 & Model & $1: 54$ & $\begin{array}{c}149,7 \\
01\end{array}$ & 0,000 \\
2 & pembelajaran & & 35,78 & 0,000 \\
3 & Pengetahuan awal & $1: 54$ & 4 & \\
& Model * & $1: 54$ & 1,310 & 0,258 \\
\hline
\end{tabular}

Hasil uji hipotesis data kemampuan pemecahan masalah menunjukkan bahwa siswa yang belajar dengan model pembelajaran kooperatif dengan pendekatan problem posing berbeda signifikan dengan siswa yang belajar dengan model pembelajaran kooperatif saja (Tabel 6). Secara ratarata model pembelajaran dengan pendekatan problem posing unggul $65,34 \%$. Hasil penelitian yang lain juga mengungkapkan bahwa pendekatan problem posing efektif untuk meningkatkan kemampuan pemecahan masalah siswa secara signifikan terhadap permasalahan-permasalahan fisika [16].

Pembelajaran berbasis problem posing membuat siswa sangat aktif dalam mencari dan menggali pengetahuannya dari berbagai macam sumber yang ada secara mandiri dan kemudian mencari permasalahan yang ada dari sumber-sumber yang dibacanya untuk kemudian diajukan sebagai masalah dalam bentuk sebuah pertanyaan. Bertanya merupakan kegiatan awal dari berpendapat. Bertanya/mengajukan suatu pertanyaan dapat memotivasi pikiran untuk maju, membuka cakrawala ilmu pengetahuan dan meminimalisir wawasan yang kaku dan sempit. Siswa tidak hanya diminta untuk membuat pertanyaan, tetapi juga harus mencari alternatif penyelesaiannya [17].
Hasil uji hipotesis pengaruh pengetahuan awal terhadap kemampuan pemecahan masalah menunjukkan bahwa siswa yang memiliki pengetahuan awal tinggi lebih baik dibandingkan siwa yang berpengetahuan awal rendah (Tabel 6). Secara rata-rata siswa yang berpengetahuan awal tinggi unggul 22,84\%. Problem posing dapat meningkatkan pemahaman siswa karena dalam prosesnya siswa mengolah informasi yang didapatkannya ke dalam pikiran dan setelah memahami informasi, siswa dapat membuat pertanyaan. Aktivitas utama siswa adalah mengajukan suatu pertanyaan. Pengajuan pertanyaan/masalah dalam pembelajaran menggunakan problem posing dapat meningkatkan kemampuan memecahkan masalah, kemampuan berpikir, dan kepercayaan diri siswa [18].

Model pembelajaran kooperatif dengan pendekatan problem posing sangat cocok diterapkan pada pembelajaran fisika khususnya dalam meningkatkan kemampuan pemecahan masalah fisika siswa. Dalam kegiatan pembelajaran, penerapannya mengaitkan dengan kehidupan sehari-hari. Siswa mengkonstruksi sendiri pengetahuannya, dari merumuskan soal hingga menentukan penyelesaiannya. Dengan demikian, pembelajaran fisika menjadi lebih bermakna dan siswa juga dapat membangun pengetahuannya sendiri melalui proses aktif dalam pembelajaran berdasarkan pengetahuan awal yang telah dimiliki, sehingga siswa yang memiliki pengetahuan awal tinggi akan dapat meningkatkan pengetahuannya dalam menyelesaikan masalah, pun siswa yang memiliki pengetahuan awal rendah akan memiliki kemampuan dalam menyelesaikan masalah fisika yang dihadapi.

Hasil uji hipotesis menunjukkan bahwa tidak ada interaksi model pembelajaran (kooperatif dengan pendekatan problem posing-kooperatif) dan pengetahuan awal siswa terhadap kemampuan pemecahan masalah. Tidak adanya interaksi antara model pembelajaran (kooperatif dengan pendekatan problem posing-kooperatif) dan pengetahuan awal siswa (tinggi-rendah) terhadap kemampuan pemecahan masalah menunjukkan bahwa pengaruh model pembelajaran kooperatif dengan pendekatan problem posing-kooperatif terhadap kemampuan pemecahan masalah tidak disebabkan oleh tingkat pengetahuan awal yang dimiliki oleh siswa, keadaan ini juga berlaku sebaliknya, yaitu pengaruh tingkat pengetahuan awal (tinggi-rendah) terhadap kemampuan pemecahan masalah tidak disebabkan oleh model pembelajaran yang digunakan guru.

Pengetahuan awal adalah sejumlah informasi yang dimiliki oleh siswa yang berkaitan dengan materi yang akan diajarkan sebelum materi tersebut disampaiakan kepada siswa, sedangkan model pembelajaran merupakan rangkaian kegiatan pembelajaran yang diberikan guru kepada siswa. Model pembelajaran kooperatif dapat mendorong 
peningkatan kemampuan siswa dalam memecahkan masalah yang ditemui selama pembelajaran, karena siswa dapat bekarja sama dengan temannya dalam menemukan dan merumuskan alternatif pemecahan masalah. Siswa yang memiliki pengetahuan awal tinggi maupun rendah akan dapat memecahkan permasalahan fisika sesuai dengan kemampuan pengetahuan yang dimiliki.

Penerapan model pembelajaran kooperatif dibarengi dengan pendekatan problem posing dapat meningkatkan kemampuan pemecahan masalah siswa menjadi semakin baik. Model pembelajaran kooperatif dengan pendekatan problem posing dapat melatih kemampuan siswa untuk berpikir kritis, dimana siswa diminta untuk merumuskan masalah/pertanyaan berdasarkan fenomena dalam kehidupan sehari-hari atau berdasarkan masalah yang diberikan oleh guru. Proses pembelajaran dengan menggunakan problem posing menuntut siswa untuk dapat melakukan dua hal, yaitu mengkomunikasikan pemikirannya melalui pengajuan masalah secara tertulis berdasarkan masalah yang ada dan memecahkan masalah dengan mencari solusi permasalahan yang telah diajukan [19].

Berdasarkan penjabaran di atas dapat dikatakan bahwa model pembelajaran (kooperatif dengan pendekatan problem posing-kooperatif) dan pengetahuan awal siswa bekerja secara terpisah dalam membantu siswa meningkatkan kemampuan pemecahan masalah fisika. Tidak ada saling ketergantungan antara model pembelajaran (kooperatif dengan pendekatan problem posingkooperatif) dan pengetahuan awal (tinggi-rendah) dalam meningkatkan kemampuan pemecahan masalah. Kedua model pembelajaran tersebut sama sama kuat memberikan pengaruh kepada siswa dalam meningkatkan kemampuan pemecahan masalah ketika diberikan kepada siswa yang mempunyai pengetahuan awal tinggi maupun siswa yang mempunyai pengetahuan awal rendah, sehingga ketika diinteraksikan maka tidak memberikan pengaruh yang signifikan terhadap kemampuan pemecahan masalah fisika.

Penggunaan problem posing menitikberatkan pada keaktifan siswa. Model pembelajaran kooperatif dengan pendekatan problem posing merupakan salah satu bentuk kegiatan dalam pembelajaran fisika yang dapat mengaktifkan siswa, mengembangkan kemampuan berpikir siswa dalam menyelesaikan masalah serta menimbulkan sikap positif terhadap fisika. Membiasakan siswa dalam merumuskan permasalahan sendiri, menghadapi dan menyelesaikan soal merupakan salah satu cara mengembangkan seni berpikir untuk mencapai penguasaan suatu konsep menjadi lebih baik dan meningkatkan kemampuan pemecahan masalah siswa.

\section{PenUTUP}

Kesimpulan berdasarkan hasil penelitian yaitu: 1) Model pembelajaran kooperatif dengan pendekatan problem posing berpengaruh terhadap kemampuan pemecahan masalah siswa, 2) Pengetahuan awal siswa berpengaruh terhadap kemampuan pemecahan masalah siswa, 3) Interaksi antara model pembelajaran (kooperatif dengan pendekatan problem posing-kooperatif) dan pengetahuan awal siswa (tinggi-rendah) tidak berpengaruh terhadap kemampuan pemecahan masalah siswa.

Pembelajaran Fisika sebaiknya tidak hanya memperhatikan penguasaan konsep siswa terhadap materi pembelajaran, melainkan juga kemampuan siswa dalam memecahkan masalah fisika sehingga melatih siswa dalam memecahkan masalah dalam kehidupan sehari-hari.

\section{REFERENSI}

[1] Hassard, J. \& Dias, M. 2009. The Art of Teaching Science. London: Oxford University Press.

[2] Brown, I.S \& Walter, I.M. 2005. The Art of Problem posing. New Jersey: Lawrence Erlbaum Associates Inc.

[3] Fiser, D. \& Frey, N. 2013. Background Knowledge: The Overlooked Factor in Reading Comprehension. McGraw Hill Network : McGraw Hill.

[4] Hailikari, T., Katajouvi, N., \& Linbrom-Ylanne, S. 2008. The Relevance of Prior Knowledge in Learning and Instructional Design. American Journal of Pharmaceutical 72(5): 113.

[5] Wink, J. 2004. Problem posing. (on line). Diakses melalui: Error! Hyperlink reference not valid., tanggal 24 Juni 2013.

[6] Pittalis, M., Cristou, C., Mousoulides, N., \& Pitta-Pantazi, D. 2004. A Structural Model for Problem posing. Proceedings of the $28^{\text {th }}$ Conference of the International Group for the Psychology of Mathematics Education, Vol 4 pp 49-56.

[7] Denim, B.B. 2005. The Effect of Instruction With Problem posing on Tenth Grade Students' Probability Achievement and Attitudes Toward Probability. Diakses melalui: http://etd.lib.metu.edu.tr/upload/ 12606884/index.pdf, tanggal 24 Juni 2012.

[8] Angelo, T.A \& Cross, K.P. 1993. Classroom Assessment Techniques. Handbook for College Teachers. San Fransisco: Jossey-Bass Publisher.

[9] Marzano, R.J. 2004. Building Background Knowledge for Academic Achievement. Alexandria, USA: Association for Supervision and Curriculum Development (ASCD). 
[10] Marzano, R.J.,\& Kendall, J.S. 2008. Designing \& Assessing Educational Objectives Applying The New Taxonomy. California: Corwin Press.

[11] Dahar, R.W. 2011. Teori-teori Belajar \& Pembelajaran. Jakarta: Erlangga.

[12] Gulo, W. 2008. Strategi Belajar Mengajar. Jakarta: Grasindo.

[13] Borg W. \& Gall, M.D. 1983. Educational Research. An Intruduction. Fourth Edition. New York: Longman, Inc.

[14] Sugiyono. 2013. Statistik Untuk Penelitian. Bandung: ALFABETA.

[15] Bao, L. 2006. Physics Education Research. Departemen of Physics. The Ohio State University. American Journal of Physics 74 (10): 917-922.

[16] Ergun, H. 2010. The Effect Of Problem Posing on Problem Solving in Introductory Physics Course .Journal of Naval Science and Engineering 6(3): 1-10.

[17] Chotimah, K. 2009. Strategi-Strategi Pembelajaran Untuk Penelitian Tindakan Kelas. Malang: Surya Pena Gemilang.
[18] Mahmudi, A. 2008. Pembelajaran Problem Posing untuk Meningkatkan Kemampuan Pemecahan Masalah Matematika. Makalah Disampaikan Pada Seminar Nasional Matematika Diselenggarakan oleh Jurusan Matematika FMIPA UNPAD Bekerjasama dengan Departemen Matematika UI.

[19] Jalil, A. 2006. Pembelajaran Dengan Pendekatan Problem Posing Untuk Meningkatkan Hasil Belajar Siswa Kelas VII SMP Negeri 4 Malang pada Konsep Sistem Hormon Tahun Pelajaran 2004/2005. Tesis Tidak Diterbitkan. Malang: Universitas Negeri Malang.

\section{Biografi Penulis}

Siti Nurdatul Jannah lahir di Rumbuk, 18 Januari 1979. Alamat rumah di J1. Gajah Mada Perum Grand Kodya Blok L No.6 RT.2 Jempong Baru Mataram. Penulis sekarang sedang menyelesaikan studi S-2 pada Prodi Magister Pendidikan Sains PPs Universitas Mataram. 